\title{
Coastal erosion in the archaeological area of Selinunte
}

\author{
V. Liguori \& A. Porcaro \\ Department of Structural, Aerospace and Geo-technical Engineering, \\ Palermo University, Italy
}

\begin{abstract}
Coast erosion is a widespread phenomenon and is a considerable issue for the dwellers of coastal areas today. Our study is based on the archaeological area of Selinunte in which we have noticed a process of erosion in progress. In this area we have considered a particular portion of the coast, around $8 \mathrm{~km}$ long, since our purpose is the individuation of anthropic elements such as ports, and natural elements, such as rivers. In this area we have set some point of reference using historical and recent cartography in a 1:25.000 scale dating back to 1971, a regional technical paper in a 1: 10.000 scale from 1994, and aerial pictures from 2000 and 2008, all of which we have geo-related starting from previous geo-related papers, locating some Ground Control Points apparent in all of the considered papers. We have used GIS support and the software program ARCVIEW. We have done a comparison between the actual shoreline and its trend in the previous years. In fact, we have measured the distance between the points considered stable on the shoreline that are changing all the time. In this way we have noticed the course of the coastline, appraising its advancement or withdrawal. The obtained data show that considering 24 stable points, in $70 \%$ of cases there has been coast withdrawal between 1994 and 2000; in 60\% there has been erosion between 2000 and 2008. From an administrative point of view, the studied area includes the territory of Castelvetrano (TP) and involves a coastline extending to around $8 \mathrm{~km}$, from the beach of Triscina-Selinunte, a fraction of Castelvetrano, to east of the mouth of River Belice. This extension has been defined as thoroughly as possible, in order to include River Belice, which is east of the archaeological park. The two analyzed rivers are Belice and Modione, both belonging to the hydrographic basin River Modione and in the area between River Modione and River Belice. From the geo-morphological point of view two
\end{abstract}


typologies of prevailing landscapes can be considered: a hilly one in the basin, in the most northern area and another one, characterizing the coastal band. The nature of the ground is predominantly clay or clayey-marl with sand breakthroughs covered by calcarenites. In this area some marine terraces are present, for example the marine terrace beneath the Acropolis of Selinunte, situated at $+50 \mathrm{~m}$ u.s.l. Another helpful element for the study of coast erosion is the discovery of an ancient port in around 1951, now buried under the sand.

Keywords: coastal erosion, sea-level change, geomorphology.

\section{Introduction}

From the administrative point of view, the studied area is in the territory of Castelvetrano (TP).

The analyzed extension has been defined according to a study as precise as possible, comprehending a portion of coast from the Belice River to the Modione River, respectively in the east and west side of the Archaeological Park. The choice of this zone is referred to as the historical-cultural and landscape interest of the archaeological area of Selinunte, whose park, founded in 1993, extends to around 270 hectares.

\section{Geology}

The lithology that characterizes this area is made of marine terrigenous deposits since the Quaternary and Calcarenite datable inferior Pleistocene and middlesuperior and middle-inferior Pliocene. These are made of sands and calcareous bioclastic gravels (Vernuccio, D’Angelo 1992 1994). These grounds cover the marly-sandy formation of the Belice Valley (Vitale 1990), constituted by a sequence of sandstones and calcarenitis intercalated by clays. Under this formation the pelagic marnosis deposits of the inferior Pliocene are tracked, denominated "Trubi" and the grounds of the evaporitic Messinian succession, evaporitic limestones and chalks, leaning on conglomerated and/or sandy and clayey-marly deposits of the Formation Cozzo Terravecchia. These grounds are affected by the presence of sea terraces since the Quaternary, characterized by sands, gravels and clays, disposed in various orders up to around $170 \mathrm{~ms}$ s.l.m. quotas (Vernuccio and D'Angelo [15]), originated in the inferior Pleistocene (Emiliano-Siciliano).

\section{Geomorphology}

The studied site is in the physiographic unity number 12 of the PAI (plain of hydro-geologic asset). This area is located on the south-western coast of Sicily. The two studied rivers are the Belice and Modione, belonging both to the hydrographic basin, River Modione, and the area between River Modione and River Belice. 
According to the technical cards of identification of the Basin Plan for the Hydro-Geological Planning, the River Modione, being the principal auction, originates near Finestrelle Mountain and its length is around $25 \mathrm{~km}$, flowing into the Mediterranean Sea. The maximum altitude is $663 \mathrm{~ms} \mathrm{s.1.m.,} \mathrm{the} \mathrm{minimum} \mathrm{is}$ 0 and the average $248 \mathrm{~ms}$ s.l.m. The total surface of the hydrographic basin is $129 \mathrm{~km}^{2} \mathrm{~s}$ and the tributaries are Staglio, Formica, Feudo, Squadrato, Riviera, Calandra and Scaldato, while the municipal territories involved are Castelvetrano, Gibellina, Partanna and Santa Ninfa.

The examined sector mainly develops in the SW direction and the bordering basins are advancing in an hourly sense from west toward east: West northwest of the Arena River's basin, north of San Bartolomeo River's basin and east of the Belice River's basin. From the geomorphologic point of view two typologies of prevailing landscapes can be tracked: hilly, in the most northern area of the basin and plane, characterizing the coastal side. The nature of the ground is predominantly clayey or marly-clayey with sand emergences. Because of the easy erosion of this lithologic type, no acclivity is noticed.

The southern portion of the Basin, which is Piana di Mazara del Vallo, is characterized by a calcarenitis roll. The clayey nature of the grounds leads to a strong erodibility that, together with acclivity features and exogenous agents, causes a physical degradation of the ground, especially where the vegetation is sparse. Zones of fondovalle often correspond to these, functioning as accumulation of eroded material. The western area of Sicily, involving the territory of Selinunte, is constituted by a series of Quaternary terraces; in particular the acropolis is situated on a terrace placed to $+50 \mathrm{~m}$ o.s.l. The whole coastal area between Marsala and Trapani, because of the sedimentary, tectonic, paleo-geographic and geomorphologic aspects, shows the bond between a tectonics of vertical lifting and the ice-eustatic oscillations. The prevailing geomorphologic aspect depends on the Quaternary terraces and the sandy coastal bands.

\section{Climate}

According to the data obtained from the study conducted at the PAI Sicilia (hydro geologic asset plan), the thermal course of the examined territory results with regular temperature average values always attested below $30^{\circ} \mathrm{C}$ and an average Basin value of $17,1^{\circ} \mathrm{C}$. Generally, the highest are recorded between July and August and in the inferior altitude areas, the lowest in February.

As far as regards the rains, anterior data obtained in thirty years (1965-1994) show an annual average precipitation of $570 \mathrm{~mm}$. The climate being primarily temperate-Mediterranean, the rainy season lasts since October to April, according to the pluviometric course typical of the Sicilian climate. The minimum heights are generally recorded in July, while the maximum in December. As regards the wind characterization, the prevailing winds blow from SW [5]. 


\section{Use of the ground}

As regards the use of the soil, from the study conducted by the P.A.I. a variegated enough distribution of the Mediterranean vegetation emerges. In fact the areas destined for agricultural use are primarily characterized by olivegroves, vineyards, almonds and prickly pear, as well as citruses. The latter ones are mostly present in the irrigated areas of Castelvetrano and Campobello di Mazara. Wheat and various fodder, are not very diffused and they are usually present in more clayey grounds. Inside the sciare, portions of never or previously cultivated ground, there is the uncultivated productive. In the whole area of such a basin only $5,26 \%$ is urbanized; in fact the agrarian landscape occupies the greatest percentage of territory.

\section{The coast of Selinunte}

The site of Selinunte has been analyzed on the basis of both geologic and archaeological markers, thanks to which we have tried to reconstruct the paleogeographic evolution of the coast, and by the use of the aerophotogrammetry managed with GIS support, that has allowed us to carry out an evaluation of the course of the coastline in the space of time of thirty years.

We have considered as geologic indicators the Sea terraces of Western Sicily, of which we own reliable data, related to the geomorphology and their date. In fact, the coast plain is characterized by the presence of a series of sea terraces found

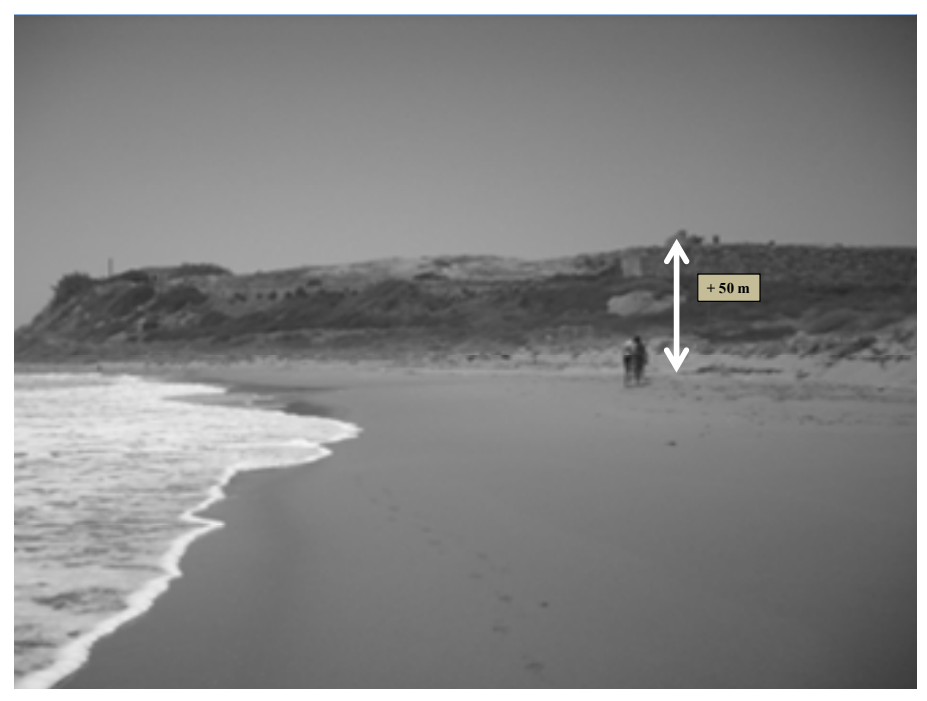

Figure 1: The acropolis of Selinunte rises on one Quaternary terrace situated at $+50 \mathrm{~m}$ o.s.l. with the mouth of the Gorgo Cottone covered by sand. 
up to altitude $+170 \mathrm{~ms}$ o.s.l. From geologic studies, the same are dated as Quaternary and particularly to medium and superior Pleistocene (120.000-10.000 years ago).

The long phase of emersion during the last ice age, after the sea invasion of the interglacial phase in the superior Pleistocene, determines a wide peneplain in Western Sicily. In the area of Campobello di Mazara, in correspondence to a broad band with course NW-SE, where the Calcarenite of Marsala appears, wide areas flattened by the Pleistocene sea can be observed, clear evidence of its abrasive action. Fossils, the most representative of which is the Strombus Bubonius, testify a warm moderate climate, typical of the interglacial periods.

These terraces appear on the surface in a wide part of the examined area, along a portion that, from a NW-SE course sub-parallel to the cliff from the Arena mouth to Torretta Granitola, extends to NE. This shows that the sea was at more elevated altitudes, compared to the current ones, equivalent to some meters beyond the level of the various terraces. Today the acropolis of Selinunte (Fig. 2), set on the western hill, is on a terrace of the Quaternary to $+50 \mathrm{~ms}$ o.s.l.

\section{Paleo-geographic reconstruction}

Through geologic and archaeological markers, the reconstruction allows us to affirm that around 800.000 years ago (Pleistocene Inferior, interglacial phase of

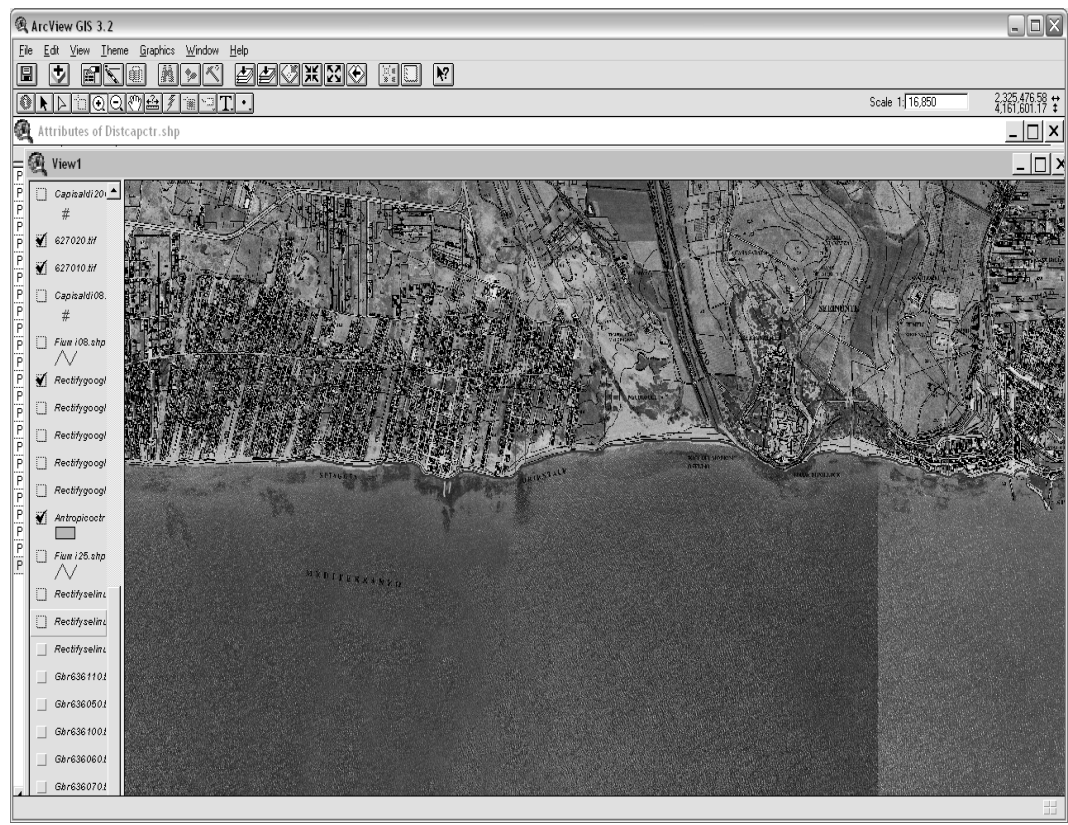

Figure 2: An example of software used to study the movement of coast line: ARCVIEW. 
the Günz-Mindel) the sea reached the maximum level and, since that moment the phase of progressive tectonic emersion of the earth started, lasting up to the Tirrenian (superior Pleistocene 120.000 years ago, Rïss-Würm). This phenomenon and the following eustatic cycles led to the formation of a stair of sea terraces. Actually, during an interglacial phase the increase of the temperature determines a rise of the sea level. At the same time the sea abrades and flattens the territory on which such transgression is in progress.

When the glacial phase takes over, in correspondence of which both the eustatic lowering of the sea level and the isostatic coast raising happen, then the emersion of the terraced surface occur. Actually, this testifies the previous presence of the sea. Then, every new formation of terrace can be associated to the transition from an interglacial phase to a glacial one.

In the western area of Sicily, to which Selinunte belongs, eight orders of marine terraces have been individualized, placed at different altitudes: $+170 \mathrm{~ms}$, $+100 \mathrm{~ms},+75 \mathrm{~ms},+50 \mathrm{~ms},+30 \mathrm{~ms},+20 \mathrm{~ms},+10 \mathrm{~ms},+3 \mathrm{~ms}$. During the middle Pleistocene the phenomenon of transgression determined a covering of vast areas of the island by the sea. This event, strongly connected with the eustatic oscillations, can be considered at the base of the formation of a weak inclination sea terrace (around $5^{\circ}$ ), that goes up to altitudes of $500 \mathrm{~ms}$ in the western Sicily. This terrace has been denominated "Great Superior Terrace" (Grande Terrazzo Superiore -Ruggeri \& Greasy 1974). In this zone the G.T.S. is between $130 \mathrm{~ms}$ and $150 \mathrm{~ms}$. The terrace on which there is the acropolis of Selinunte is set to +50 $\mathrm{ms}$ and it is datable as Tirrenian (superior Pleistocene -120.000 years ago, interage phase of the Rïss-Würm). From this we deduce that in the following glacial phase of the Superior Pleistocene (Würm) the sea starts again to lower because of eustasy and the coast starts to rise because of isostasy, up to the Olocene phase (10.000 years ago-today), when the sea starts rising again, considered the interglacial period $[1-3,6,15]$.

Around 2500 years ago (Olocene) the presence of a port is certainly attested in Selinunte. In fact, the archaeological marker that we are studying can be connected to this period, characterized by the Greek colonization, allowing us to formulate a reconstruction of the sea course in coincidence to the Selinunte coast. This port is not visible today, being covered by around $2 \mathrm{~ms}$ of sand, situated along the mouth of the Gorgo Cottone River with a reduced course that used to flow in the eastern side of the acropolis. Its age is difficult to attest, because of unfinished and unpublished excavations, even if its presence is noticed since the VII century B.C. The archaeological studies underline the existence of another port that probably was on the mouth of the Sèlinos River (current Modione). The first excavations showing this dock go back up to the end of the $19^{\text {th }}$ century and were performed by Cavallari. Subsequently the structure was covered by sand, to be recovered again in 1902 .

Once again, the structure was covered by sand and only in 1950-1951 some excavations were performed by Bovio Marconi. Also at this time the work was kept unpublished and the dock was covered again by the sand, resulting in it being practically nonexistent today. Some photos, taken during the periodical and alternate excavations, show the port location that can be placed in 


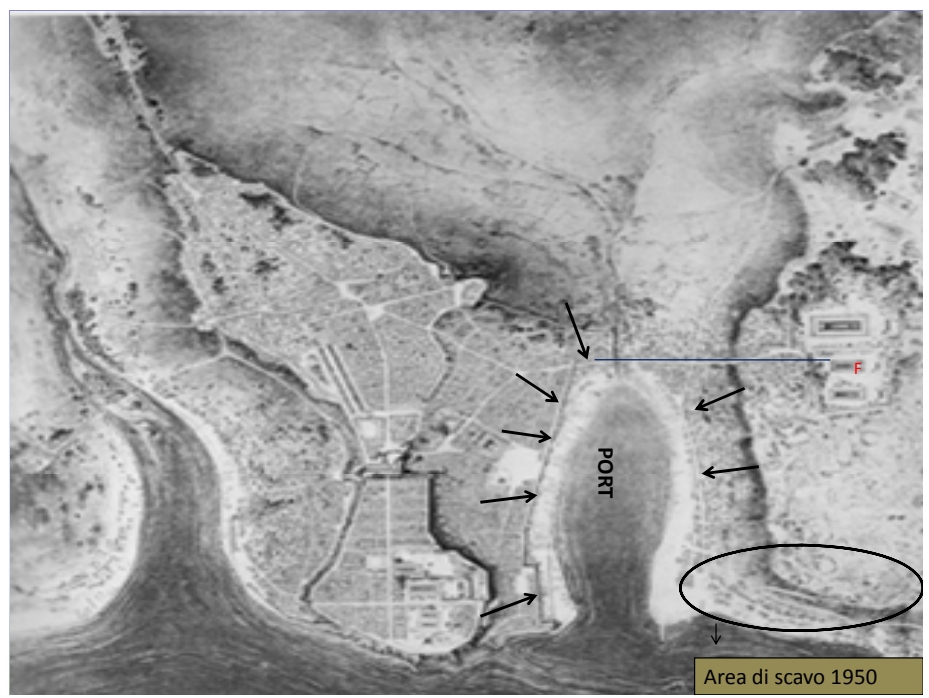

Figure 3: Ancient Greek port of Selinunte situated on Gorgo Cottone; the black line connects graphically the old bound of shore and the temple F.

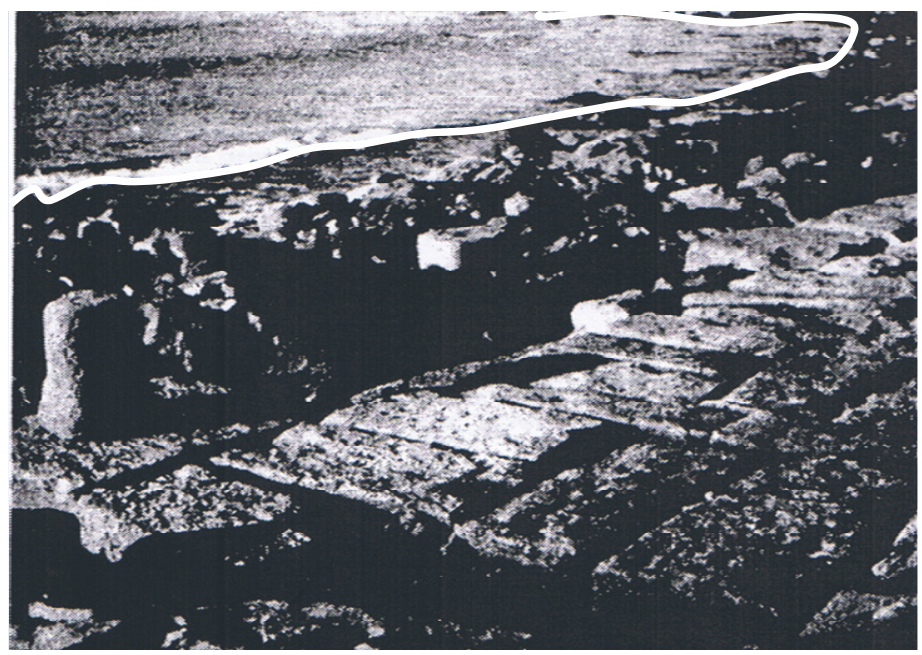

Figure 4: Gorgo Cottone, ancient Greek port of Selinunte, excavation of 1950-1951.

correspondence of the mouth of the dried Gorgo Cottone river, actually on the sea. This would lead us to believe that two factors caused the disappearance of the structure: on the one hand the withdrawal of the sea, phenomenon to be placed during the Olocene, even if as a sporadic event, considered the typical inter-age phase, however documented by the curve of Siddal and from the other, the sanding by the dune system. Besides, the tectonic lifting of the area must be 
considered. Particularly, on the basis of graphic reconstructions, it is possible to observe that the most internal border of the invasion area of the sea, that is the port structures, in terms of length arrived in correspondence to the left colonnade of the temple F (looking at the Acropoli), the most ancient of the oriental hill temples, whose construction goes back to middle VI century B.C.

The zone, from a morphological point of view, is made of three areas: the first is on the oriental hill, where three temples are placed (among which the temple $\mathrm{F}$ ); the second on the western hill encircled by walls, on which the acropolis is situated, at $50 \mathrm{~ms}$ o.s.l.; finally the third one, west of the acropolis, represented another sacred area with temples and sanctuaries. Between the oriental hill and the acropolis hill, a vast level land extends that was crossed by the Gorgo Cottone, and coincidently is where the old port was placed (Fig. 4). Today this whole area is dried up; an operation of reforestation has been effected in the beach, with trees of eucalyptus and typical Mediterranean plantations.

\section{Coastline surveys}

In the case of Selinunte, being a sandy coast in which the moves of the coast are more appreciated in planimetry than altimetry, we have developed a study with GIS support.

To conduct a detailed study of the erosive phenomenon, we have individualized some temporal arcs as reference to make a comparison in the various periods of time.

We have focused in particular on a period since the Seventies to 2008. The first phase has been focused on the retrieval of the cartographic and photographic material. We have used historical and recent cartography as CTR (Regional Technical chart) in scale 1:10000, and aerial photos. The years of reference are 1994, 2000 and 2008. Such paper support has been scanned and acquired in

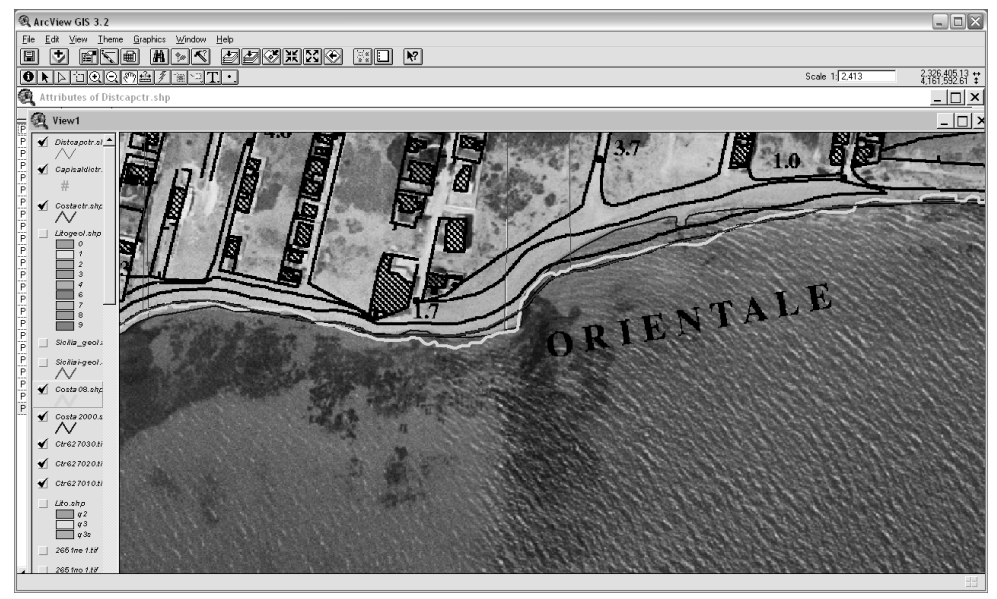

Figure 5: Here it is possible to observe that the shorelines of 2000 and 2008 are in withdrawal, in comparison with the shoreline of 1994. 
digital format to be managed by GIS, with the programs ARCVIEW 3.2 and ARCMAP.

Before the graphic job we have geo-referred both the cartography and the aerial photos, transferring them in a system of geographical reference where to each sector and represented object corresponded the correct geographical coordinates. Such procedure has been developed using as base a geo-referred cartography and introducing some GCP (ground control point), that are checkpoints visible on both supports, numerous enough to cover the area to be geo-referred homogeneously. Then, the whole cartographic and photographic material has been treated with ARCVIEW, through the creation of different themes and particularly the coastline referred to the graphic support of the considered period has been traced. The studied coastlines extend in length for around $8 \mathrm{~km}$. This choice can be connected to the intention to individualize time after time the anthropic elements as harbours and the natural ones as rivers, in order to connect all the different components. Subsequently, some traceable strongholds have been singled out in each examined paper or photo. From these points the distances from the coastline have been measured, being able to appraise, this way, the withdrawal or the advancement of the same between a period and another. In every line, seeing underlined different strongholds, a representative average value has been got, drawn as prevailing behaviour.

From the study conducted with the aid of the graphic-digital support, once individualized 24 strongholds, it has been noticed that in around $70 \%$ of them, a withdrawal coastline occurred in the years since 1994 to 2000 and around $60 \%$ since 2000 to 2008. Graphic analysis has been conducted on a CTR paper in scale 1:10.000 developed in 1994, on a photogram referred to a flight of 2000 and finally on an aerial photo taken in 2008. The studied coastline has been divided in 7 transects, comprising respectively a number of strongholds varying between 3 and 4 of which a withdrawal and an advancement of the coastline has been noticed as follows:

From the obtained data, results show that in strongholds number 9 and 10 an advancement of the coastline is recorded, both in 2000 in comparison to 1994, and in 2008 in comparison to 2000. Considering that the strongholds are immediately west from the port of Marinella di Selinunte and that the prevailing direction of the winds in this area is S-W and also observing the presence of the Belice river on the west side of the port, the results show that the port construction constitutes a real barrier to the natural solid transport, causing an accumulation behind it. Another element that must be considered to confirm this thesis is the consequent withdrawal of the coastline in correspondence of the strongholds 12 and 13 , situated immediately to east of the port area $[4,7-12,16$, 17].

\section{Sea level change}

During the geological eras the level of the sea has always suffered some oscillations, whose incidence changes in the time and from a zone to the other. 


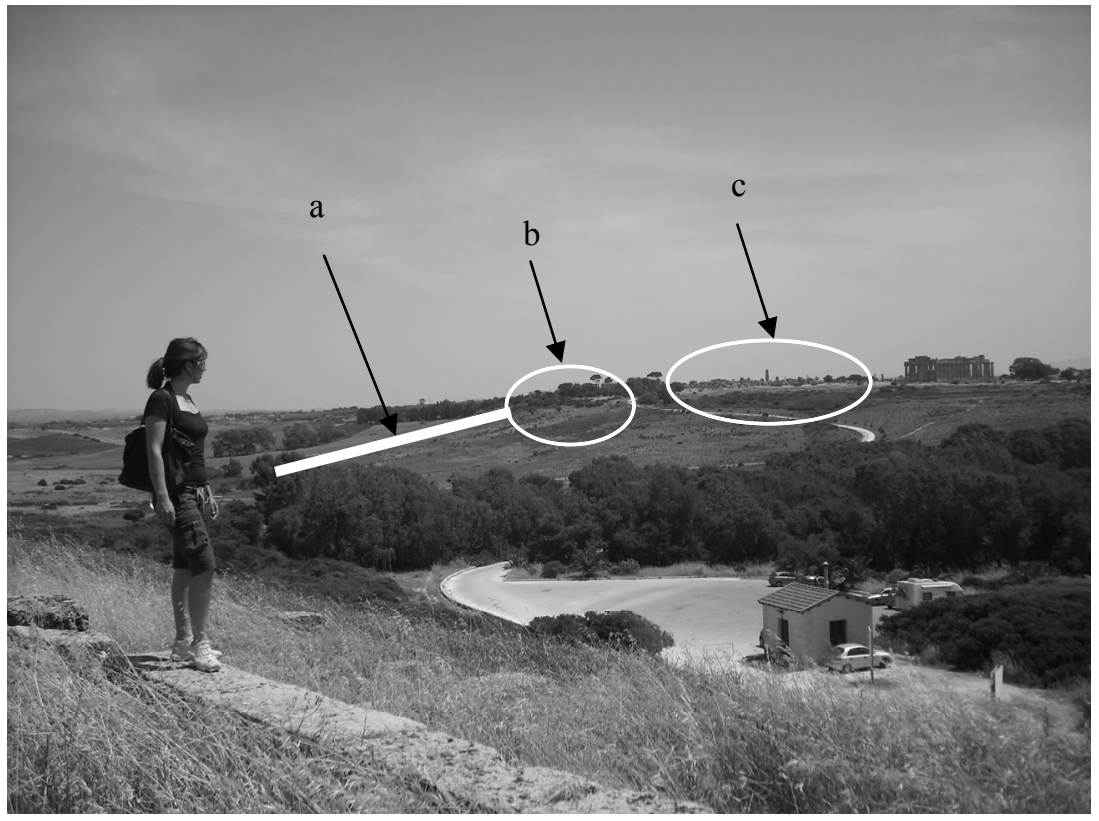

Figure 6: Sight of the Gorgo Cottone from the terrace to $+50 \mathrm{~ms}$ on which the acropolis of Selinunte (hill to the west) rises. It is possible to identify the valley's weak inclination, in which prior to 2500 years ago the sea had entry (a), which entered the hinterland to reach the colonnade of the temple F (b). Set behind is the temple (c).

Such changes, manifesting as raisings and lowering of the sea level, are identified with the term eustasy. For 9000 years, since the beginning of the last interglacial phase, the geologic data record an increase of the volume of the oceans, but it remains to clarify if this continued in the recent past (Lambeck et al 2004). This is important to establish if the cause of the current increase of the sea level is the global warming or if it forms part of natural events not connected with human activity. Authoritative studies claim that the beginning of the new lifting of the sea is to place around 100-150 years ago (Lambeck et al 2004). On the basis of literature data and studies developed by authoritative scientists, today it can be affirmed that the relative lifting of the sea is caused by the following natural movements $[6,13,14]$ :

$$
V L M=\text { Eustas } y+\text { tectonic }+ \text { isostasy (glacial and hydro) }
$$

- $\quad$ Eustasy (or eustatism): Increase or lowering of the sea level due to a variation of volume or water mass. The current ascent in the oceans, due to the only contribution of the eustasy, is valued at $1,8 \mathrm{~mm} / \mathrm{year}$ and in the Mediterranean at 1,2 $\mathrm{mm} /$ year.

- Tectonics: Lifting or lowering of the continental plates, causing as a repercussion the movement of the coastal band locally: bradisism (positive and 
negative) and subsidence. The causes can be attributed to tectonic (theory of the plates tectonics), geophysical (volcanic eruptions) and anthropic (drainage of water, oil and gas) phenomena. The tectonic contribution in the Mediterranean oscillates between $-1 \mathrm{~mm} /$ year and $+2.4 \mathrm{~mm} /$ year.

- Isostasy: lifting or lowering of the terrestrial crust as a mechanical response to load or unload of a weight causing a pressure. The phenomenon distinguishes itself in glacial-isostasy and hydro-isostasy: the first one is connected to the weight of the ice masses; the second is connected to the weight of waters that alternatively are released or stoked in the glaciers. In the Mediterranean the rate of isostatic variation is $0,2-1 \mathrm{~mm} / \mathrm{year}$ (for the Mediterranean they are negative values). In the glaciers, $30 \mathrm{Km}^{3}$ of water are stoked today.

Table 1: Distance ground control point-coast in CTR (technical regional chart) in 1994.

\begin{tabular}{|c|c|c|c|c|c|c|c|c|c|c|c|}
\hline 1 & 2 & 3 & 4 & 5 & 6 & 7 & 8 & 9 & 10 & 11 & 12 \\
\hline $416 \mathrm{~m}$ & $428 \mathrm{~m}$ & $418 \mathrm{~m}$ & $425 \mathrm{~m}$ & $136 \mathrm{~m}$ & $226 \mathrm{~m}$ & $245 \mathrm{~m}$ & $561 \mathrm{~m}$ & $461 \mathrm{~m}$ & $345 \mathrm{~m}$ & $549 \mathrm{~m}$ & $168 \mathrm{~m}$ \\
\hline 13 & 14 & 15 & 16 & 17 & 18 & 19 & 20 & 21 & 22 & 23 & 24 \\
\hline $386 \mathrm{~m}$ & $70 \mathrm{~m}$ & $507 \mathrm{~m}$ & $160 \mathrm{~m}$ & $59 \mathrm{~m}$ & $415 \mathrm{~m}$ & $377 \mathrm{~m}$ & $301 \mathrm{~m}$ & $506 \mathrm{~m}$ & $292 \mathrm{~m}$ & $265 \mathrm{~m}$ & 256 \\
\hline
\end{tabular}

Table 2: $\quad$ Distance ground control point-coast in the orto-picture of 2000; $(+)$ advancing coast; (-) coast in withdrawal in comparison with the situation of 1994 .

\begin{tabular}{|l|l|l|l|l|l|l|l|l|l|l|l|}
\hline 1 & 2 & 3 & 4 & 5 & 6 & 7 & 8 & 9 & 10 & 11 & 12 \\
\hline $\begin{array}{c}424 \mathrm{~m} \\
(+)\end{array}$ & $\begin{array}{l}\mathrm{m} \\
\mathrm{m}\end{array}$ & $\mathrm{m}$ & $\mathrm{m}$ & $\mathrm{m}$ & $\mathrm{m}$ & $\mathrm{m}$ & $\mathrm{m}$ & $\mathrm{m}$ & $\mathrm{m}$ & $\mathrm{m}$ & $\mathrm{m}$ \\
& $(+)$ & $(-)$ & $(+)$ & $(-)$ & $(-)$ & $(+)$ & $(+)$ & $(-)$ & $(+)$ & $(-)$ & $(-)$ \\
\hline
\end{tabular}

\begin{tabular}{|l|l|l|l|l|l|l|l|l|l|l|l|}
\hline 13 & 14 & 15 & 16 & 17 & 18 & 19 & 20 & 21 & 22 & 23 & 24 \\
\hline 383 & $66 \mathrm{~m}$ & 499 & 159 & $58 \mathrm{~m}$ & 404 & 353 & 284 & 495 & 286 & 264 & 273 \\
$\mathrm{~m}$ & $(-)$ & $\mathrm{m}$ & $\mathrm{m}$ & $(-)$ & $\mathrm{m}$ & $\mathrm{m}$ & $\mathrm{m}$ & $\mathrm{m}$ & $\mathrm{m}$ & $\mathrm{m}$ & $\mathrm{m}$ \\
$(-)$ & & $(-)$ & $(-)$ & & $(-)$ & $(-)$ & $(-)$ & $(-)$ & $(-)$ & $(-)$ & $(+)$ \\
\hline
\end{tabular}


Table 3: $\quad$ Distance ground control point-coast in the orto-picture of 2008; $(+)$ advancing coast; (-) coast in withdrawal; (---) stable condition. The first symbol is related to the comparison with 1994; the second symbol is related to the situation of 2000 .

\begin{tabular}{|c|c|c|c|c|c|c|c|c|c|c|c|}
\hline 1 & 2 & 3 & 4 & 5 & 6 & 7 & 8 & 9 & 10 & 11 & 12 \\
\hline $\begin{array}{l}418 \mathrm{~m} \\
(+), \\
(-)\end{array}$ & $\begin{array}{l}437 \\
\mathrm{~m} \\
(+) \\
(+)\end{array}$ & $\begin{array}{l}414 \mathrm{~m} \\
(-), \\
(+)\end{array}$ & $\begin{array}{l}422 \mathrm{~m} \\
(-), \\
(-)\end{array}$ & $\begin{array}{l}135 \\
\mathrm{~m} \\
(-) \\
(+)\end{array}$ & $\begin{array}{l}215 \\
\mathrm{~m} \\
(-) \\
(-)\end{array}$ & $\begin{array}{l}248 \\
\mathrm{~m} \\
(+) \\
(--)\end{array}$ & $\begin{array}{l}565 \\
\mathrm{~m} \\
(+) \\
(+)\end{array}$ & $\begin{array}{l}449 \\
\mathrm{~m} \\
(-) \\
(-)\end{array}$ & $\begin{array}{l}360 \\
\mathrm{~m} \\
(+) \\
(+)\end{array}$ & $\begin{array}{l}547 \\
\mathrm{~m} \\
(-) \\
(-)\end{array}$ & $\begin{array}{l}67 \mathrm{~m} \\
(-) \\
(--)\end{array}$ \\
\hline
\end{tabular}

\begin{tabular}{|l|l|l|l|l|l|l|l|l|l|l|l|}
\hline 13 & 14 & 15 & 16 & 17 & 18 & 19 & 20 & 21 & 22 & 23 & 24 \\
\hline $382 \mathrm{~m}$ & $68 \mathrm{~m}$ & $497 \mathrm{~m}$ & $157 \mathrm{~m}$ & $53 \mathrm{~m}$ & $398 \mathrm{~m}$ & 347 & 282 & 488 & $276 \mathrm{~m}$ & 255 & 254 \\
$(-)$ & $(-)$, & $(-)$, & $(-)$, & $(-)$, & $(-)$, & $(-)$, & $\mathrm{m}$ & $\mathrm{m}$ & $(-)$ & $\mathrm{m}$ & $\mathrm{m}$ \\
$(-)$ & $(+)$ & $(-)$ & $(-)$ & $(-)$ & $(-)$ & $(-)$ & $(-)$, & $(-)$ & $(-)$ & $(-)$ & $(-)$ \\
& & & & & & & $(-)$ & $(-)$ & & $(-)$ & $(-)$ \\
\hline
\end{tabular}

Table 4: $\quad$ Obtained data.

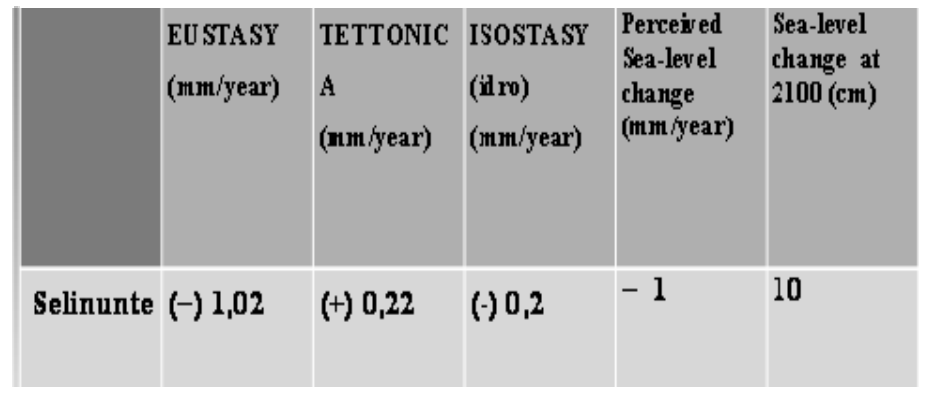

\section{References}

[1] Antonioli F., Variazioni del livello del mare nell'ultimo semiciclo glaciale ottenute da speleotemi in grotte sommerse di aree costiere italiane, ISNN 0392-0534, Studi Trent. Sci. Nat., Acta Geol., 80 (2003), pp. 49-53, 2005

[2] Antonioli F, Utilizzo del mare come livello di base per calcoli sulla mobilità verticale. Atti del congresso AIQUA CNR, Il sollevamento Quaternario nella penisola italiana e nelle aree limitrofe, Roma, 6-8 February 2006, volume degli abstract, (2006).

[3] Antonioli F., K. Lambeck, A. Purcell, S. Silenzi 2004, Sea-Level change along the Italian coast for the past $10.000 \mathrm{yr}$, Quaternary Science Reviews 23 (2004), "Elsevier", pp. 1567-1598 
[4] Benassai E., P. Cataldo, A. Ragone - Modificazione della fisiografia delle spiaggie sottili per effetto di insediamenti portuali. Atti del Seminario " $L a$ Difesa delle Coste nella Gestione del Territorio Regionale”, Pescara, 1978. Quaderni Formez, n. 18, Roma, 1979.

[5] Ferrara V., A. Farruggia, Clima: istruzioni per l'uso- I fenomeni, gli effetti, le strategie, 2007

[6] Gehrels, W. R. Sea-level changes since the Last Glacial Maximum: An appraisal of the IPCC Fourth Assessment Report. J. Quat. Sci. (in press) (2008).

[7] Liguori V., Vulnerability assessment of a coastal sector in south Sicily (Italy). Atti del $5^{\circ}$ European Congress on Regional Geoscientific Cartography and information systems ("ECONGEO”); vol. 1, pp. 510-513, Barcelona, 13-16 June 2006.

[8] Liguori V., Integrated Management of the Marsala coast (Sicily): application of a new evaluation method. Atti del $5^{\circ}$ "European Congress on Regional Geoscientific Cartography and Information system" ("ECONGEO”); vol. 1, pp. 514-516; Barcelona 13-16 June 2006.

[9] Liguori V., Assessment of coastal vulnerability in South Sicily (Italy). $2^{\text {nd }}$ International Conference on the Management of Coastal Recreational Resources-Beaches, Yachting and Coastal Ecotourism, Gozo, Malta 2006.

[10] Liguori V., The San Leone dunes: geomorphological environment and management. Workshop on integration of the geomorphological environment and cultural heritage, Malta 2007.

[11] Liguori V., The San Leone (Agrigento) dunes: coastal geomorphology. IV Reunion de geomorfologia litoral, Territoris, Universitat de les Illes Balears, 2007

[12] Liguori V., F. Cigna, G. Manno, Tecniche di monitoraggio delle spiagge, Un'esperienza nel Mediterraneo, METIC (Mediterranean Trading and Innovation Centre), pp. 97-121, 2008.

[13] Pirazzoli P.A., Cambiamenti globali e variazioni del livello del mare: meccanismi e tendenze evolutive, Mare e cambiamenti globali- pp. 15-27, 2000 ICRAM, 2000.

[14] Pirazzoli P.A.1986, Secular Trends of relative sea-level (RSL) changes indicated by tide-gauge records, Journal of Coastal Research, Special Issue, Vol. I, 1986, pp. 1-26

[15] Vernuccio S., U. D’Angelo, I terrazzi quaternari della estremità occidentale della Sicilia, Mem. Soc. Geol. It., 51 (1996), 585-594, 8ff, 1996.

[16] Wöppelmann, G., Miguez, B. M., Bouin, M. \& Altamimi, Z. Geocentric sea-level trend estimates from GPS analyses at relevant tide gauges worldwide Glob. Planet. Change 57, 396-406 (2007).

[17] Wunsch, C., Ponte, R. M. \& Heimbach, P. Decadal trends in sea level patterns: 1993-2004. J. Climate 20, 5889-5911 doi: 10.1175/2007JCLI1840.1 (2007). 